Meta

Journal des traducteurs

Translators' Journal

\title{
A Queer Trade
}

\section{General Observations on Commercial Translation}

\section{Ray J. Pollet}

Volume 12, numéro 3, septembre 1967

URI : https://id.erudit.org/iderudit/003850ar

DOI : https://doi.org/10.7202/003850ar

Aller au sommaire du numéro

\section{Éditeur(s)}

Les Presses de l'Université de Montréal

\section{ISSN}

0026-0452 (imprimé)

1492-1421 (numérique)

Découvrir la revue

Citer cet article

Pollet, R. J. (1967). A Queer Trade: General Observations on Commercial

Translation. Meta, 12(3), 81-84. https://doi.org/10.7202/003850ar d'utilisation que vous pouvez consulter en ligne.

https://apropos.erudit.org/fr/usagers/politique-dutilisation/ 


\section{A \\ QUEER TRADE}

\section{GENERAL OBSERVATIONS}

\section{ON COMMERCIAL TRANSLATION}

The Club of Queer Trades is a society consisting exclusively of people who have invented some new and curious way of making money.

\section{G.K. Chesterton}

The Club of Queer Trades

\section{EN GARDE}

The English-speaking commercial market is so vast, and the Anglo-American language so versatile in its semantic flexibility, that other languages in this North American business world have for too long been relegated to a minority role.

The recent upsurge of French in North America has altered trends and will continue to do so; but the process is a slow one, because there is little time in a materialistic cosmos like ours for problems which, on the surface, appear to be of a mere literary or linguistic nature.

We live in an age of jets, hooliganism, sadistic crime, money imperialism and monoxide poisoning; it is the era of the coke-and-hamburger culture, as well as of overcommercialization and devastating business practices. The handling of such behavioral patterns demands an ever-increasing knowledge of markets and mass media. Faced with such a world, the commercial translator too often has to answer abrupt requests from business lords for services that meet their basic norms: something good and original (of course), readily understandable (obviously), fast (a sign of the times), and not too expensive (often a false standard of modern business).

The art of translation, especially in the commercial field, is still grossly misunderstood and, above all, sadly underestimated. Businessmen are interested only in extending their market outlets and in meeting foreign competition for the 
sole purpose of increasing profits. Most are highly practical men but, when it comes to factual appreciation of transposition work into another language to attain their monetary aims, their practicality seems to vanish. The true value of such work escapes many. They do not realize how vital translation is: the entire success of their ventures will frequently depend upon the way in which advertising and other commercial texts have been adapted to reach people of other cultures.

To judge the quality of a translated text, to fully appreciate the value of the work involved, such as the correctness of semantics and style, as well as the overall advertising appeal and commercial impact, businessmen should be endowed with a natural gift for linguistics. Needless to say, this is a training most do not have or take time to acquire, and in which they often show no interest. Because, after all, you are the specialist. The acceptance that you are the artist does not give your principals a true insight into all aspects of such top quality achievement nor an appreciation of its true worth in dollars and cents.

Commercial translation or adaptation requires men who have a lot more than a good academic training and theoretical book knowledge. They should keep abreast of modern developments and trends in business; they should remain in contact with those who speak a different tongue, cnjoy a different culture and often follow different business practices. These factors, to name but a few, should be familiar to a good commercial translator. He should have a special gift for empathy and a flair for ethnology without which it is difficult to transpose something into another reality, to create something that does not smell of artificiality. Indeed, one should always remember that commercial translation must strive for advertising appeal and direct buying impact.

It is a Queer Trade, a difficult and demanding one. But it is an interesting and rewarding occupation because of the amplitude and completeness of the task.

A conscientious commercial translator should always undertake a thorough study of his topic, in order to incorporate vital data as well as some color into his transposition. Otherwise, he would risk producing mere sexless gibberish, barely understandable, void of commercial impetus, and therefore without value as a profit-earning weapon.

\section{ENTRECHATS}

This chapter has nothing to do with the animal kingdom of cats. However, as long as there are semantic entrechats performed by «while-U-wait » charlatans, and texts ordered today "for yesterday ", there will be a sick language as well as a fair amount of easy money to be found by the cads of this queer trade. But for the dedicated, for those who still believe in honesty of purpose, the problems at hand remain intricate as long as business executives refuse to realize that cheaper or cut rates often mean inferior work while, similarly, high rates in exchange for speedy service do not always spell out quality.

We cannot insist enough on the many facets of a trade in which the translator transposes so much more than words and meanings: he has to create an imagemaking entity that will overcome people's foetal resistance to unfamiliar ideas, and reach markets promptly and profitably. 
The necessity of taking into account a wide variety of data is especially true when it comes to the rendering of fairly touchy subjects for various ethnic markets.

Let us imagine, for example, that commercial translators are entrusted with the rendition for both North American and European markets of advertising texts promoting the sale of some unusual items, as follows:

- products to relieve the periodic pains of spinsters longing for menopausal serenity;

- playboy versions of the Scriptures, as an all-out public relations effort by churches to bring back the straying;

- sterling silver navel plates as an added decor for beauties in monokini, as well as to protect their carnal epicenter from the corroding effects of ocean water and industrial dust.

It is obvious that one English version may not hit the market the same way in New York, Chicago, Los Angeles, Montreal or old London. Similarly, the French rendition of the same material may not strike equally in Montreal, Quebec City, Paris, Brussels or Geneva.

A touch of cautious arrogance may trick gallant Britons into impulse buying, while a similar textual approach in French may fall flat in Paris or Quebec. Paris may call for some more spiritedness, braggadocio and flamboyance. Smaller provincial towns in France or Quebec may require a more prudent approach, void of excess truculence; such places may demand a premeditated blend of sanctity and bluntness to achieve the same results.

A flash of emancipation in an otherwise not-too-audacious advertising context may even appeal to those in remote locations, where old traditions and religious ukases are being slowly superseded by the materialistic superficiality of the teenage psychedelic revolution.

A preened presentation is another prerequisite, whenever compatible with the urgency of business requirements; for well-organized translators, this can always be arranged. Still, many clients seem satisfied with draft-like presentations which, sometimes, both they and translators endeavor to excuse on the ground that content is all that counts, and that untidy layouts may be the result of last-minute entrechats with semantics and advertising technicalities. In fact, sloppy presentations are often a symbol of confusion and may carry little commercial value.

We are actually in the age of a new lingo, a lingua-franca, a pidgin AngloAmerican. We may even try to analyze this linguistic cocktail: a dash of «psychosomatic » new words coined to cover up our ignorance of certain subjects; an overdose of simple existing words of the « gadget $»$ type, to stigmatize our poverty of expression; a horrendous escalation in the use of IBM perforations, and innumerable signs and abbreviations. The above ingredients have contributed generously toward crippling whatever limpidity and grace remain in the spoken and written language.

Much has been said concerning commercial jargon and its syntactical heresies. An ethical language will always strike more forcibly. But the fact remains that the language of commerce and publicity sometimes does require the emphasis created by an obvious grammatical blur or the twang of a slangish term. In the 
world of direct advertising, occasional impurity of language often helps masses to get the message.

However, the crusade to maintain and improve the basic correctness of language should continue unabated. To prevent the menacing return to the apian age of shrieks, grimaces and direct physical communication, our depersonalized cosmos needs a true revitalization of the art of simple expression and contact between people. In this connection, one may rejoice that nations have so far survived the maddening tempo of the twentieth century, and that man still retains his human outlook and a disposition to remain terrestrial, despite irrepressible spatial curiosity.

\section{ENVOI}

If commercial translation is to be something more than the ornate rendition of glorified clichés, something solid, creative and direct, we must abide by some communal rules.

Businessmen should understand that translation or adaptation is one of the primary arts, one of the fundamental cogs in the intricate commercial world, and not a minor evil that they have to put up with in their search for foreign markets. Commercial translation is an indispensable means of wider social communication. It is vital in the struggle for new marketing outlets.

Texts badly written, drafted in haste or wrongly adapted into the language of another ethnic group may prove fatal to both client and translator, ruin the growing popularity of some new product, and often result in severe financial loss. The lastminute submission of texts for rush translation is too frequently due to the compulsion of most business executives to keep up with the frenzy of modern times, as well as to lack of internal organization of many firms, large and small.

Requests by conscientious translators for extra time in order to produce better jobs should always be met sympathetically. Such legitimate delays may allow for increased overall quality. In all probability, the resulting work will be more effective as a communication weapon, as an asset in the hands of business executives in eager search of expansion.

The outlay for good commercial translation should be measured by the amount of work involved and by the recognized ability of the translator. An outlay of this nature may sometimes appear excessive at first, as do most expenses. But it should never be considered merely as an immediate incidental disbursement; rather, it is a true capital expenditure when one anticipates that benefits derived therefrom will often be of a continuing nature.

As in any other profession, some commercial translators enjoy very substantial earnings, while a great many more just manage to survive. Although the race for more money is in fact one of the greatest diseases of our time, it should never overshadow professional standards. Sacrificing one's art knowingly, prostituting knowledge and quality for mere financial expediency, can only endanger the profession as a whole and ruin this noble but often Queer Trade, a craft which, as poet Paul Verlaine once wrote, "est une œuvre de choix qui veut beaucoup d'amour».

Ray J. Pollet 